\title{
RELEVANSI PEMBELAJARAN MATEMATIKA DENGAN NILAI-NILAI AL-QUR'AN DALAM MEMBENTUK KARAKTER SISWA PADA MATERI PECAHAN
}

\author{
Fenny Anggreni \\ Institut Agama Islam Negeri Langsa, jalan Meurandeh, Langsa 24411, Indonesia \\ Email: fenny@iainlangsa.ac.id
}

\begin{abstract}
Abstrak
Tujuan pendidikan matematika adalah mempersiapkan siswa agar sanggup menghadapi perubahan keadaan di dalam kehidupan dan dunia yang selalu berkembang melalui bertindak atas dasar pemikiran secara logis, rasional, kritis, cermat, efektif dan efisien. Berdasarkan tujuan pendidikan matematika diharapkan siswa mampu mempersiapkan diri dalam kehidupan baik di bidang akademik dan non akademik seperti moral siswa. Tujuan penelitian ini untuk mengetahui apa saja ayat-ayat Al-Quran yang berkaitan dengan materi pecahan dan nilainilai karakter apa saja yang muncul pada pembelajaran matematika berbasis Al-Quran pada materi pecahan. Adapun metodologi penelitian ini yaitu penelitian deskriptif. subjek penelitian ini yaitu siswa kelas VII.1 MTsN Aceh Tamiang yang berjumlah 30 siswa. Adapun hasil penelitian ini yaitu ayat-ayat Al-Quran yang berkaitan dengan materi pecahan yaitu QS An Nisa ayat 11, 12 dan 176 tentang warisan serta QS Al-Baqarah ayat 267 tentang zakat dan nilai-nilai karakter yang muncul pada pembelajaran matematika berbasis Al-Quran pada materi pecahan yaitu tanggung jawab, adil dan peduli sosial.
\end{abstract}

Kata kunci: Pembelajaran Matematika, Nilai-Nilai Al-Quran, Karakter Siswa, Pecahan

\begin{abstract}
The aim of mathematics education is to prepare students to be able to deal with changing conditions in life and the world that always develops through acting on the basis of logical, rational, critical, careful, effective and efficient thinking. Based on the objectives of mathematics education students are expected to be able to prepare themselves in life both in the academic and non-academic fields such as student morale. The purpose of this study is to find out what are the verses of the Koran that are related to fraction material and what character values appear in Al-Quran based mathematics learning in fractions. The research methodology is descriptive research. The subjects of this study were class VII.1 MTsN Aceh Tamiang which numbered 30 students. The results of this study are the verses of the Koran relating to the fraction material, namely QS An Nisa verses 11, 12 and 176 about inheritance and QS Al-Baqarah verse 267 concerning zakat and character values that appear in Al-based mathematics learning The Quran on fractions is responsible, fair and socially concerned.
\end{abstract}

Keywords: Mathematics Learning, Al-Quran Values, Student Characters, Fractions

\section{PENDAHULUAN}

Pendidikan merupakan faktor yang penting peranannya di dalam proses kehidupan dan perkembangan suatu bangsa. Di negara yang sedang berkembang seperti Indonesia, peningkatan kualitas pendidikan harus terus ditingkatkan agar menghasilkan manusia berpotensi yang nantinya akan berguna bagi nusa dan bangsa. Sebagaimana ditetapkannya tujuan pendidikan nasional, yang rumusannya ada pada Undang-Undang Sisdiknas Bab I pasal 3 tertulis sebagai berikut "Pendidikan Nasional berfungsi mengembangkan kemampuan dan membentuk watak serta peradaban bangsa,bertujuan untuk berkembangnya potensi peserta didik agar menjadi manusia yang beriman dan bertakwa kepada Tuhan Yang Maha Esa, berakhlak mulia, sehat, berilmu, cakap, kreatif, mandiri dan menjadi warga negara yang demokratis serta bertanggung jawab" (Dakir, 2004: 24). 
Pendidikan seharusnya tidak hanya berbicara mengenai hal-hal yang bersifat akademik saja, namun juga non akademik khususnya tentang sikap dan bagaimana perilaku sehari-hari yang baik. Inilah yang disebut dengan pendidikan moral. Pendidikan karakter dan pendidikan moral selama ini dilakukan secara parsial dan dianggap menjadi tanggung jawab dan wewenang guru-guru tertentu. Penanaman nilai religius dianggap menjadi domain guru agama melalui Pendidikan Agama Islam (PAI), sedang penanaman nilai, moral, toleransi, nasionalisme diserahkan pada guru PPKn. Guru tersebut secara faktual mempunyai keterbatasan baik dalam hal alokasi waktu maupun otoritas dan kapasitas untuk mengkaitkan dengan kontekstual kehidupan. Akibatnya, ada alienasi nilai dari realitas kehidupan, sehingga pendidikan moral dan penanaman nilai relatif kurang berhasil.

Kekurangberhasilan penanaman nilai dan karakter melalui pendekatan parsial baik di sekolah secara khusus maupun di masyarakat secara umum, tampak pada menurunnya moral generasi muda kita. Indikator yang sangat nyata adalah semakin meningkatnya para pelajar yang terlibat dalam tindakan pidana, seperti tawuran, penggunaan narkoba, pencurian, pemerkosaan, pergaulan bebas dan sebagainya. Serentetan catatan berikut menunjukkan potret buram pelajar dan remaja Indonesia. Sekitar 200.000 remaja terlibat sebagai pecandu Narkoba; 1/3 penderita AIDS di Indonesia adalah remaja; Sekitar 2,4 juta aborsi terjadi tiap tahun, 700 ribu di antaranya dilakukan oleh remaja. Bahkan Humas Polda Metro Jaya menyebutkan bahwa tahun 2003-2004 terjadi tawuran antar pelajar sebanyak 19 orang pelajar SLTP 100 orang pelajar SLTA dengan korban luka ringan sebanyak 38 orang, luka berat 3 orang dan tewas 2 orang (Hanafiah, 2007: 4). Jika realitas ini dibiarkan seperti apa adanya, maka bukan mustahil potret pelajar dan remaja Indonesia semakin buram (Mujahidin, 2005: 7). Oleh karena itu perlu adanya suatu formula dalam bidang pendidikan yang diharapkan mampu menjadi solusi dari permasalahan-permasalahan tersebut.

Matematika sebagai bagian dari kurikulum pendidikan, diharapkan menjadi sarana bagi pencapaian tujuan pendidikan yang telah ditetapkan yakni adanya perubahan sikap dan tingkat laku anak didik yang mencakup didalamnya terbentuknya pribadi yang bermoral seperti komitmen, jujur, kerjasama, kreatif, sopan santun, sikap ilmiah, sikap toleran, demokratis, disamping kemampuan berfikir matematis yang berpijak pada pemikiran yang logis dan sistematis. Dengan demikian pembelajaran matematika diharapkan tidak hanya mampu mengantarkan siswa pada keberhasilan belajar matematika yang diwujudkan dalam bentuk prestasi, tetapi juga adanya perubahan sikap dan moral.

Kenyataan ini sudah cukup untuk menjadi alasan guna membenahi atau memperbaiki sistem pendidikan nasional yang saat ini sedang terpuruk. Penanaman moral yang baik dalam diri peserta didik perlu dilakukan secara serius dan terus-menerus melalui suatu program yang terencana. Upaya tersebut dalam kontek lembaga pendidikan tidak semata-mata menjadi tugas guru 
Pendidikan Agama Islam (PAI)saja tetapi menjadi tugas dan tanggung jawab bersama, termasuk guru matematika.

Al-Quran memberikan jawaban-jawaban yang terkini mengenai pendidikan moral sebagaimana terdapat dalam Al-Quran surat Al-Hujarat ayat 6 yang artinya:"Wahai orang-orang yang beriman, jika datang kepada kamu berita dari orang-orang fasik, maka telitilah terlebih dahulu agar kamu tidak menimpakan suatu musibah kepada kaum tanpa mengetahui keadaannya yang menyebabkan kamu menyesal atas perbuatan itu"

Ayat ini menggambarkan setiap orang untuk memeriksa secara teliti dan cermat atas informasiinformasi yang ada agar tidak menimpakan malapetaka kepada orang lain. Pendidikan moral seharusnya mampu diterapkan dalam berbagai pelajaran, termasuk pelajaran matematika yang juga sarat dengan pendidikan moral di dalamnya. Dengan Belajar matematika dapat melatih peserta didik menjadi manusia yang lebih teliti, cermat dan tidak ceroboh dalam bertindak. contohnya ketika memecahkan permasalahan tentang fungsi matematika peserta didik harus memperhatikan dengan teliti berapa angkanya, berapa digit nol dibelakang koma, grafiknya, dan bagaimana titik potongnya. Setelah peserta didik memperhatikan hal tersebut kemudian peserta didik harus cermat dalam membaca permasalah pada materi tersebut. Jika tidak cermat dan teliti dalam membaca permasalahan dan memasukan angka, melihat grafik atau melakukan perhitungan, tentu bisa menyebabkan hasil yang kita peroleh tersebut salah dan kadang berbeda jauh dengan jawaban sebenarnya.

Penelitian terdahulu yang mengulas tentang pendidikan matematika yaitu penelitian yang ditulis dalam jurnal SEMNASDIK yang berjudul "Matematika dan Al-Quran untuk Membentuk Pendidikan Berkarakter Islami” Yang ngulas tentang alquran dan pendidikan berkarakter dalam matematika (Nur Indah sari: 2017) dan Makalah dalam seminar Nasional Matematika dan Pendidikan Matematika FMIPA UNY Yogyakarta, 9 November 2013 yang berjudul "Pendidikan Moral Matematika" mengulas tentang Keberhasilan pendidikan moral matematika merupakan simbol keberhasilan pendidikan matematika kita. Artinya kalau pembelajaran matematika berhasil, maka konsep matematika berhasil dipahami dan dihayati dalam sanubari siswa dan hal ini akan tercermin dalam prinsip hidup, cara pandang, tutur kata dan tingkahlaku para penanggungjawab negeri dimasa yang akan datang( Sundarini, Sri; 2013), Penelitian yang ditulis dalam Jurnal Penelitian Vol. 10, No. 1, Mei 2013. Hlm. 63-76 yang berjudul "Pendidikan Karakter Melalui Pembelajaran Matematika"mengulas tentang pelaksanaan pendidikan karakter melalui pembelajaran matematika yang menghasilkan hasil belajar lebih baik dari pada metode pembelajaran konvensional (Salafuddin, 2013), Penelitian yang ditulis dalam Jurnal Ilmiah WIDYA Volume 1 Nomor 2 Juli-Agustus 2013 yang berjudul “ Membentuk Karakter Melalui Pendidikan Moral Pada Anak Usia Dini Di Sekolah Raudhatul Athfal (R.A) Habibillah' hasil penelitiannya yaitu (1) Metode pendidikan 
pembacaan doa-doa harian dan surat-surat pendek Al-Qur'an dalam rangka membentuk karakter peserta didik sangat efektif dimana kemampuan yang dimiliki peserta didik dapat memperlihatkan perilaku mereka sehari-hari di sekolah. Moral mereka sudah mencerminkan perilaku yang Islami. (2) Proses pembelajaran yang dilakukan guru- guru adalah langsung mendekatkan diri kepada siswa yang ingin bermain atau mengobrol dengan temannya di saat proses pembelajaran berlangsung ( Ahmad Gunadi, Andi : 2013).Penelitian ini berbeda dengan penelitian-penelitian diatas. Penelitian ini, memiliki fokus penelitian memperoleh gambaran mengenai pembelajaran matematika dan relevansinya dengan nilai-nilai al-quran dalam membentuk pendidikan moral bagi siswa. Dan dikaji secara mendalam dalam literatur al-quran dan buku serta jurnal tentang pendidikan moral, serta dijelaskan langkah penerapan pembelajaran matematika di sekolah, metode penelitian yang digunakan adalah penelitian kualitatif. Pada penelitian ini akan menunjukkan bahwa pendidikan moral dapat diterapkan pada seluruh mata pelajaran yang ada disekolah, tidak hanya mata pelajaran tertentu yang membahas materi nilai-nilai moral.

Berangkat dari permasalahan di atas, penulis tertarik untuk meneliti mengenai matematika dan relevansinya dengan nilai-nilai al-Quran sehingga mampu membentuk karakter masyarakat yang bermoral dan beradab. Tujuan penelitian ini untuk mengetahui apa saja ayat-ayat Al-Quran yang berkaitan dengan materi pecahan dan nilai-nilai karakter apa saja yang muncul pada pembelajaran matematika berbasis Al-Quran pada materi pecahan.

\section{METODE PENELITIAN}

\section{Rancangan Penelitian}

\section{Jenis Penelitian}

Jenis penelitian dalam penelitian ini adalah penelitian kualitatif metode deskriptif. Penelitian kualitatif yaitu suatu penelitian untuk meneliti kondisi objek alamiah dimana peneliti adalah sebagai instrumen kunci (Riduwan, 2010:51).penelitian deskriptif adalah penelitian yang menggambarkan apa adanya tentang sesuatu variabel, gejala atau keadaanyang diteliti (Arikunto, 2007:234)

\section{Waktu dan Tempat penelitian}

Adapun tempat penelitian ini di MTsN Aceh Tamiang yang terletak di jalan Raya B.AcehMedan KM. 457 Tualang Cut dan waktunya mulai tanggal 16 Juli s/d 10 Agustus 2018.

\section{Subjek Penelitian}

Adapun subjek penelitian ini yaitu siswa kelas VII.1 MTsN Aceh Tamiang yang berjumlah 30 siswa. Subjek diambil secara acak menggunakan teknik Simple Random Sampling. Simple Random Sampling adalah teknik sampling yang dilakukan secara acak dengan menggunaan undian, ordinal, tabel bilangan random dan komputer (Usman, Husaini, 2006:183). 


\section{Instrumen Data}

Instrumen data pada penelitian ini menggunakan lembar observasi untuk melihat proses pembelajaran matematika secara apa adanya.

\section{Teknik Analisis Data}

Analisis data adalah proses memberikan interpretasi dan arti bagi data yang telah dikumpulkan dengan cara diurutkan sesuai pola, kategori, dan satuan uraian sehingga dapat lebih mudah digunakan untuk menjawab permasalahan-permasalahan yang ada dalam penelitian. Dalam menganalisis data, digunakan teknik deskriptif kualitatif untuk memberikan interpretasi terhadap hasil penelitian atau data yang diwujudkan dengan uraian yang berbentuk kalimat yang akhirnya ditarik suatu kesimpulan untuk menunjukkan fakta di lapangan.

\section{HASIL PENELITIANDAN PEMBAHASAN}

\section{Penerapan Materi Pecahan}

Di awal pembelajaran guru menyampaikan degan ayat-ayat yang berkaitan dengan pecahan, seperti ayat di bawah ini

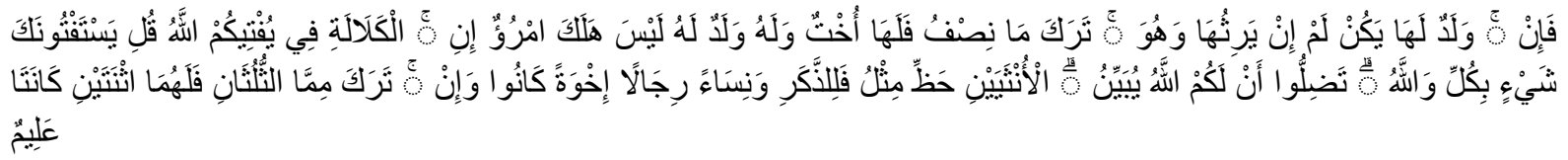

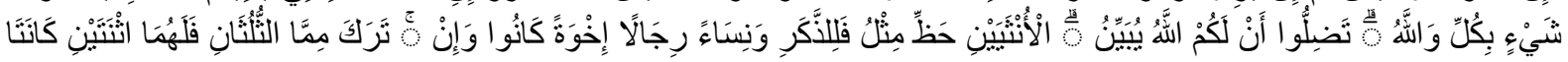
عَليّم

176. Mereka meminta fatwa kepadamu (tentang kalalah)[387]. Katakanlah: "Allah memberi fatwa kepadamu tentang kalalah (yaitu): jika seorang meninggal dunia, dan ia tidak mempunyai anak dan mempunyai saudara perempuan, Maka bagi saudaranya yang perempuan itu seperdua dari harta yang ditinggalkannya, dan saudaranya yang laki-laki mempusakai (seluruh harta saudara perempuan), jika ia tidak mempunyai anak; tetapi jika saudara perempuan itu dua orang, Maka bagi keduanya dua pertiga dari harta yang ditinggalkan oleh yang meninggal. dan jika mereka (ahli waris itu terdiri dari) saudara-saudara laki dan perempuan, Maka bahagian seorang saudara laki-laki sebanyak bahagian dua orang saudara perempuan. Allah menerangkan (hukum ini) kepadamu, supaya kamu tidak sesat. dan Allah Maha mengetahui segala sesuatu. (QS. An Nisa' ayat 176)

[387] Kalalah Ialah: seseorang mati yang tidak meninggalkan ayah dan anak.

Pada ayat di atas Allah menjelaskan tentang pembagian harta warisan tentang kalalah yang didalamnya terdapat jumlah seperdua dan dua pertiga, dimana seperdua dan dua pertiga itu termasuk bilangan di dalam Matematika. Hal ini menunjukkan bahwa Al-Qur'an juga berbicara mengenai Matematika, jauh sebelum para ilmuwan menemukan Matematika. Hal ini menunjukkan salah satu kemukjizatan dari Al Quran. Matematika adalah sebuah cabang ilmu pengetahuan yang wajib dipelajari dan sering kita jumpai dalam kehidupan sehari-hari. Salah satunya seperti kata seperdua, dan dua pertiga pada Surat An Nisa ayat 176 di atas dimana dalam Matematika dapat ditulis dengan angka $\frac{1}{2}$ dan $\frac{2}{3}$

\section{Pengertian Pecahan}


Jika sebuah kue dibagi menjadi dua bagian yang sama maka setiap bagian adalah $\frac{1}{2}$ bagian dari seluruhnya.

- Jika sebuah kue dibagi menjadi empat bagian yang sama maka setiap bagian adalah $\frac{1}{4}$ bagian dari seluruhnya.

- $\frac{1}{2}$ dan $\frac{1}{4}$ disebut pecahan

- Pada pecahan $\frac{1}{2}$ angka 1 disebut pembilang dan angka 2 disebut penyebut

\section{Pecahan Senilai}

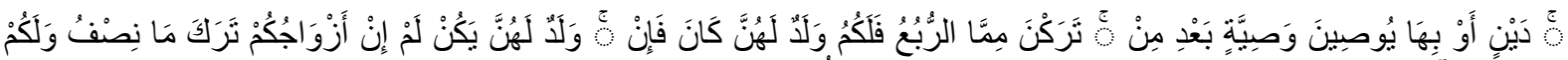

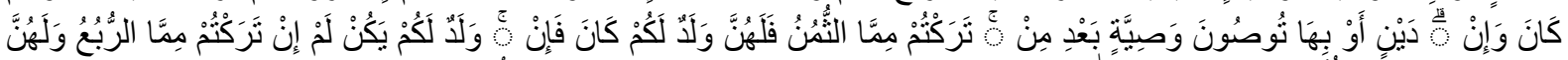

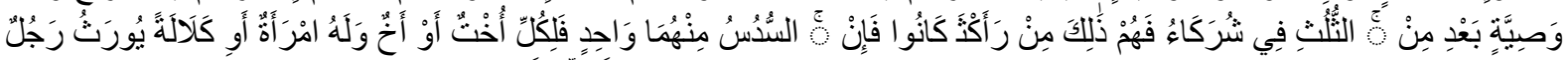

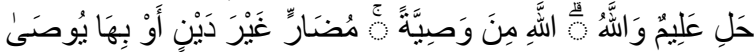

12. dan bagimu (suami-suami) seperdua dari harta yang ditinggalkan oleh isteri-isterimu, jika mereka tidak mempunyai anak. Jika isteri-isterimu itu mempunyai anak, Maka kamu mendapat seperempat dari harta yang ditinggalkannya sesudah dipenuhi wasiat yang mereka buat atau (dan) sesudah dibayar hutangnya. Para isteri memperoleh seperempat harta yang kamu tinggalkan jika kamu tidak mempunyai anak. Jika kamu mempunyai anak, Maka Para isteri memperoleh seperdelapan dari harta yang kamu tinggalkan sesudah dipenuhi wasiat yang kamu buat atau (dan) sesudah dibayarhutanghutangmu. Jika seseorang mati, baik laki-laki maupun perempuan yang tidakmeninggalkan ayah dan tidak meninggalkan anak, tetapi mempunyai seorang saudaralaki-laki (seibusaja) atau seorang saudara perempuan (seibusaja), Maka bagi masing-masing dari keduajenis saudara itu seperenam harta. Tetapi jika saudara-saudara seibu itu lebih dari seorang, Maka mereka bersekutu dalam yang sepertiga itu, sesudah dipenuhi wasiat yang dibuat olehnya atau sesudah dibayarhutangnya dengan tidak memberimudharat (kepada ahli waris)[274]. (Allah menetapkan yang demikian itu sebagai) syari'at yang benar-benardari Allah, dan Allah Maha mengetahui lagi Maha Penyantun.

Pada ayat di atas Allah menjelaskan pembagian warisan. Diantaranya adalah pembagian warisan suami dan istri. Dalam ayat ini Allah menjelaskan bahwa bagi para suami harus memiliki tanggungjawab kepada istrinya walaupun ia telah meninggal dunia. Sikap tanggung jawab adalah salah satu sikap terpuji yang harus dimiliki oleh setiap manusia.

Pada ayat diatas Allah menyebutkan seperdua dariharta yang ditinggalkan oleh isteri jik amereka tidak mempunyai anak. Kata seperdua pada Surat AnNisa ayat 12 diatas di dalam Matematika dapat di tulis dengan $\frac{1}{2}$ dan termasuk kedalam pecahan.

Perhatikan gambar dibawah ini, 


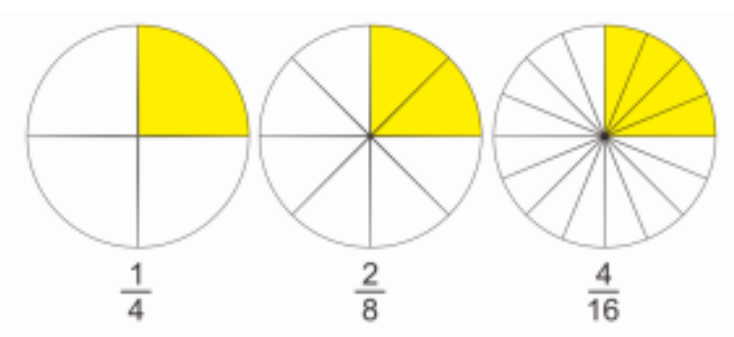

Dari gambar diatas dapat terlihat bahwa $\frac{1}{4}, \frac{2}{8}$, dan $\frac{4}{16}$ memiliki ukuran yang sama, dengan begitu pecahan-pecahan tersebut bias dikatakan pecahan senilai

Secara umum dapat dituliskan :

Bila diketahui, pecahan $\frac{a}{b}$ dengan $\mathrm{b} \neq 0$ maka berlaku $\frac{a}{b}=\frac{a \cdot n}{b \cdot n}$ atau $\frac{a}{b}=\frac{a \cdot m}{b \cdot m}$, dimana $\mathrm{n}$ dan $\mathrm{m}$ konstanta positif bukan nol.

\section{Membandingkan dua Pecahan}

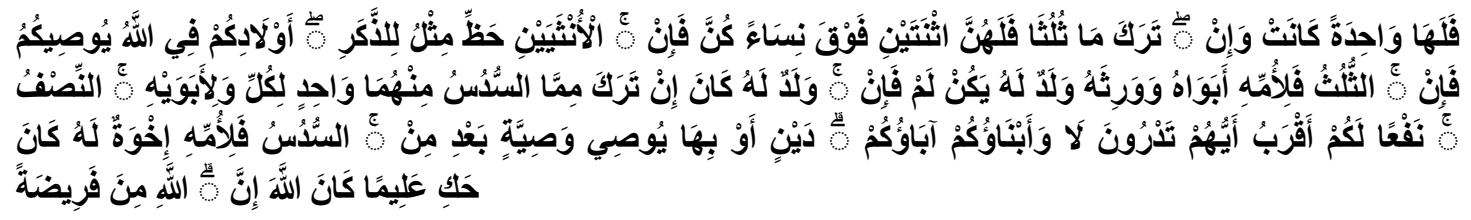

11. Allah mensyari'atkan bagimu tentang (pembagian pusaka untuk) anak-anakmu. Yaitu :bahagian seorang anak lelaki sama dengan bahagian dua orang anak perempuan[272]; dan jika anak itu semuanya perempuan lebih dari dua[273], Maka bagi mereka dua pertiga dari harta yang ditinggalkan; jika anak perempuan itu seorang saja, Maka ia memperoleh separo(seperdua) harta. Dan untuk dua orang ibu-bapa, bagi masing-masingnya seperenam dari harta yang ditinggalkan, jika yang meninggal itu mempunyai anak; jika orang yang meninggal tidak mempunyai anak dan ia diwarisi oleh ibu-bapanya (saja), Maka ibunya mendapat sepertiga; jika yang meningga litu mempunyai beberapa saudara, Maka ibunya mendapat seperenam. (Pembagian-pembagian tersebut di atas) sesudah dipenuhi wasiat yang ia buat atau (dan) sesudah dibayar hutangnya. (Tentang) orang tuamu dan anak-anakmu, kamu tidak mengetahui siapa di antara mereka yang lebih dekat (banyak) manfaatnya bagimu. Ini adalah ketetapan dari Allah. Sesungguhnya Allah Maha mengetahui lagi Maha Bijaksana.

Pada ayat di atas Allah menjelaskan tentang pembagian warisan, diantaranya adalah pembagian warisan bagi anak. Pembagian ini bertujuan untuk tidak saling memperebutkan harta warisan. Allah mengatur kita dalam berbagai hal termasuk dalam hal sekecil apapun salah satunya adalah berlaku Adil kepada sesama. Sifat adil merupakan salah satu sikap yang harus kita tanamkan sejak dini. Di dalam pecahan kita dapat membandingkan pecahan satu dengan pecahan lainnya seperti ketentuan di bawah ini :
1. $\frac{a}{b}$ lebih dari $\frac{p}{q}$, ditulis sebagai $\frac{a}{b}>\frac{p}{q}$
2. $\frac{a}{b}$ kurang dari $\frac{p}{q}$, ditulis sebagai $\frac{a}{b}<\frac{p}{q}$
3. $\frac{a}{b}$ sama dengan $\frac{p}{q}$, ditulis sebagai $\frac{a}{b}=\frac{p}{q}$ 


\section{Pecahan Desimal dan Persentase}

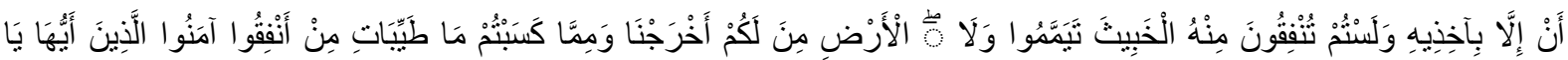

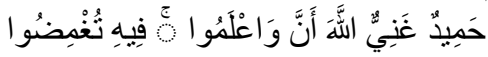

267. Hai orang-orang yang beriman, nafkahkanlah (di jalan Allah) sebagian dari hasil usahamu yang baik-baik dan sebagian dari apa yang Kami keluarkan dari bumi untuk kamu. dan janganlah kamu memilih yang buruk-buruk lalu kamu menafkahkan daripadanya, Padahal kamu sendiri tidak mau mengambilnya melainkan dengan memincingkan mata terhadapnya. dan ketahuilah, bahwa Allah Maha Kaya lagi Maha Terpuji. (QS. Al-Baqarah ayat 267 )

Pada ayat di atas allah menjelaskan tentang pembagian zakat hasil. Setiap orang yang mempunyai kelebihan hasil dalam usahanya maka wajib atasnya mengeluarkan zakat kepada orangorang yang membutuhkan. Dalam hal ini Allah mengajarkan hambanya untuk bersikap peduli sosial kepada sesama manusia. Kita sebagai manusia harus menanamkan sikap peduli sosial dalam kehidupan kita. Sikap peduli sosial itu sendiri termasuk kedalam karakter yang harus ditanamkan pada setiap anak didik.

Jadi, salah satu cara kita menanamkan sifat peduli sosial adalah dengan cara mengeluarkan zakat dari hasil usaha/ profesi kita sehingga berdasarkan Surat Al-Baqarah ayat 267, para ulama berpendapat bahwa zakat hasil/profesi ada dua jenis pelaksanaan, sesuai jenis pendapatan manusia.

1. Orang yang gajian bulanan, maka pendekatannya dengan zakat tanaman, yaitu nishabnya adalah 5 wasaq, senilai dengan $653 \mathrm{Kg}$ gabah kering giling, dan dikeluarkan 2,5\%, yang dikeluarkan ketika menerima hasil (gaji), tidak ada haul.Nishab zakat penghasilan perbulan disamakan dengan nishab pertanian yaitu $520 \mathrm{~kg}$ beras atau sebesar Rp. 5.200.000,-. Berartiwajib zakat.

2. Orang yang penghasilannya bukan bulanan, seperti tukang jahit, kontraktor, pengacara, dokter, dan semisalnya, menggunakan pendekatan zakat harta, yakni nishab senilaidengan $85 \mathrm{gr}$ emas setelah diakumulasi dalam setahun, setelah dikurangi hutang konsumtif, dikeluarkan sebesar $2,5 \%$. Nishab zakat penghasilan pertahundisamakan dengan nishab emas yaitu 85 gr emas atau sebesar Rp. 51.000.000,-. Berarti wajib zakat.

\section{KESIMPULAN}

Adapun hasil penelitian ini yaitu penerapan pembelajaran matematika pada materi pecahan direlevansikan dengan ayat-ayat Al-Quran tentang warisan, pada surat An Nisa ayat 11, 12 dan 176, serta QS Al-Baqarah ayat 267 tentang zakat. Nilai-nilai karakter yang muncul pada penerapan pembelajaran matematika yang direlevansikan dengan pecahan yaitu tanggung jawab, adil dan peduli sosial. 


\section{REFERENCES}

Ahmad Gunadi, Andi ,(2013), Membentuk Karakter Melalui Pendidikan Moral Pada Anak Usia Dini Di Sekolah Raudhatul Athfal (R.A) Habibillah', Jurnal Ilmiah WIDYA Volume 1 Nomor 2 Juli-Agustus 2013

Arikunto, Suharsimi. (2009) Dasar-Dasar Evaluasi Pendidikan, Jakarta:Bumi Aksara.

Dakir. (2004). Perencanaan danPengembangan Kurikulum. Jakarta: Rineka Cipta

Mujahidin, Endi, (2005), Pesantren Kilat Alternatif Pendidikan Agama di Luar Sekolah, Jakarta Timur : Pustaka Al-Kautsar

Nur Indah sari, Dkk,(2017), Matematika dan Al-Quran untuk membentuk Pendidikan Berkarakter Islami ,Proseding seminar nasional Pendidikan, Universitas Muhammadiyah

Riduwan. (2007). Belajar Mudah Penelitian untuk Guru-Karyawan dan Peneliti Pemula. Bandung: Alfabeta.

Salafuddin, (2013), Pendidikan Karakter Melalui Pembelajaran Matematika" Penelitian yang ditulis dalam Jurnal Penelitian Vol. 10, No. 1, Mei 2013.

Sundarini, Sri, (2013), Pendidikan Moral Matematika, Makalah dalam seminar Nasional Matematika dan Pendidikan Matematika FMIPA UNY Yogyakarta ISBN : 978 - $979-16353-9-4,9$ November 2013

Usman, Husaini \& Purnomo Setyady. (2006) Pengantar Statistika. Jakarta: Bumi Aksara 